\title{
A revision of mid-Cretaceous textularian foraminifers from Texas
}

\author{
ALFRED R. LOEBLICH \& HELEN TAPPAN \\ Department of Earth and Space Sciences, University of California, Los Angeles, California 90024 U.S.A.
}

\begin{abstract}
As Cretaceous species previously placed in Bigenerina, Siphotextularia, and Textularia differ from typical Cenozoic representatives of these genera in having solid noncanaliculate walls, 16 species from the Fredericksburg and Washita Groups (AlbianCenomanian) of Texas and Oklahoma have been restudied. The new genera Heterantyx with type species H. antonovae sp. nov. and Quasispiroplectammina with type species Spiroplectammina longa are assigned to the family Spiroplectamminidae. A new family Textulariopsidae is proposed for basically biserial taxa with solid walls and includes Plectinella, Textulariopsis, of which two species $T$. lechriosa and $T$. texhomensis are new, the reinstated genus Bimonilina, with a new species B. reciprocata, and three new genera, Aaptotoichus, Haimasiella and Minyaichme.
\end{abstract}

\section{INTRODUCTION}

The presence of perforated or canaliculate walls in agglutinated foraminifera has been sporadically observed but taxonomically neglected. Study of Recent and other Cenozoic species by various workers (Hofker, 1951, 1976; Coleman, 1980; Banner \& Pereira, 1981) suggests that a greater emphasis should be placed on such wall characters. Thus, Banner \& Pereira (1981) transferred from Textularia the Cretaceous taxa with solid walls, and regarded these as a new genus Textulariopsis which they placed in the subfamily Verneuilininae, family Ataxophragmiidae.

In working on a foraminiferal suprageneric reclassification, we have reexamined certain mid-Cretaceous assemblages from the American Gulf Coast that we had studied earlier, including species originally described as Bigenerina, Siphotextularia, Spiroplectammina, and Textularia. Most of the species were originally described in the 1930's and 1940's, hence solely on the basis of light microscopy. As most are relatively tiny species, details of wall character were not evident. For the present paper we have restudied these species and a few additional new species, and have examined half-sectioned specimens in the scanning electron microscope (SEM) to determine the character of their walls.

\section{METHODS}

In addition to study and camera-lucida illustration of these species with the light microscope, half sections were prepared of each species with the method described by Hofker (1933) and Coleman (1979). Specimens embedded in paraffin were ground on a 600 size carborundum sheet using castor oil as a lubricant; after polishing and removal of the paraffin in xylene, specimens were mounted on plugs for SEM examination.
All were found to have solid, noncanaliculate walls, although this is not surprising in view of their very thin walls and generally small size.

\section{MATERIAL}

Material for the present study has been collected by us over many years from various outcrop localities in north and central Texas and southern Oklahoma. Only those localities are listed below from which specimens are illustrated herein. This material is from the Goodland Formation of the Fredericksburg Group and from all units of the overlying Washita Group, in Oklahoma and north Texas, in ascending order the Duck Creek Formation, Fort Worth Formation, Denton Formation, Weno Formation, Paw Paw Formation, Main Street Formation and Grayson Formation, the Duck Creek to Main Street equivalent Georgetown Formation and Grayson equivalent Del Rio Formation of Central Texas, and the youngest Washita unit, the subsurface Maness Formation of east Texas. In addition, cores taken from the deep sea on the Blake Escarpment in the Atlantic Ocean were studied.

Locality 1. Grayson Formation at Grayson Bluff, a high, S.W.-facing bluff on Denton Creek, $3.2 \mathrm{~km} \mathrm{E}$. of Fort Worth-Denton highway, $5.6 \mathrm{~km}$ N.E. of Roanoke, Denton County, Texas. Collected April, 1937.

Locality 9. Fort Worth Formation, in deep road cut on W. side of U.S. highway 75, the Denison-Durant road, $300 \mathrm{~m} \mathrm{~N}$. of Calvary Cemetery, $0.8 \mathrm{~km} \mathrm{~N}$. of Texas Highway Department information station, $2.5 \mathrm{~km}$ north of Main Street in Denison, Grayson County, Texas. Collected July, 1938.

Locality 13. Duck Creek Formation, on W. bank of Red River in the S.W. 1/4, Sec. 22, T. 8S., R. 2E., on S.W. 
side of Horseshoe Bend, Love County, Oklahoma. Collected August, 1939.

Locality 36. Main Street Formation, in a road cut about $0.4 \mathrm{~km}$ along road leading E. to Grayson Bluff from Fort Worth-Denton highway, $5.6 \mathrm{~km} \mathrm{N.E.} \mathrm{of} \mathrm{Roanoke} \mathrm{and}$ $1.6 \mathrm{~km} \mathrm{E}$. of the highway, Denton County, Texas. Collected September, 1938.

Locality 39. Fort Worth Formation, in the bank of a tributary to Hickory Creek, just N. of the small concrete bridge over the creek, $2 \mathrm{~km} \mathrm{N.W}$. of Krum, Denton County, Texas. Collected September, 1938.

Locality 40. Paw Paw Formation, in S. bank of Denton Creek, just W. of U.S. highway 377 (Fort WorthDenton highway), where it crosses Denton Creek, $5.6 \mathrm{~km} \mathrm{N.E.} \mathrm{of} \mathrm{Roanoke,} \mathrm{Denton} \mathrm{County,} \mathrm{Texas.}$ Collected September, 1938.

Locality 44. Fort Worth Formation, on S. bank of Sycamore Creek, about $15 \mathrm{~m} \mathrm{E}$. of Fort WorthCrowley road, where it crosses the creek, $2.5 \mathrm{~km} \mathrm{~S}$. of the Baptist Seminary Campus, in Fort Worth, Tarrant County, Texas. Collected July, 1940.

Locality 47. Weno Formation, on S. bank of a tributary to Sycamore Creek, which was dammed to form Katy Lake, $0.4 \mathrm{~km}$ E. of and below the Katy Lake Dam. S.E. of Fort Worth, Tarrant County, Texas. Collected September, 1938.

Locality 48. Fort Worth Formation, on E. side of U.S. highway 77 , just $\mathrm{S}$. of a small bridge, $1.6 \mathrm{~km} \mathrm{W.S.W.} \mathrm{of}$ Gainesville courthouse square, Cooke County, Texas. Collected July, 1940.

Locality 55. Paw Paw Formation, in a road cut on $N$. side of road, at W. edge of Federal Narcotic Farm, S.E. of Fort Worth, Tarrant County, Texas. Collected June, 1939.

Locality 56. Fort Worth Formation, in a road cut in the 1700 block of East Lancaster Street, just W. of the corner of Riverside Drive and Lancaster Street, on Fort Worth-Dallas highway (U.S. 80), in Fort Worth, Tarrant County, Texas. Collected June, 1939.

Locality 57. Duck Creek Formation, in a road cut on E. side of U.S. highway 77, just S. of bridge across Red River, Cooke County, Texas. Collected June, 1939.

Locality 73. Goodland Formation, N. side of road, $6 \mathrm{~km}$ W. of Montgomery Street on Old Stove Foundry Road (Vickery Boulevard), at Cragin Knob, in Fort Worth, Tarrant County, Texas. Collected August, 1941.

Locality 90. Del Rio Formation, on W. bank of Shoal Creek, just S. of bridge of 34th Street, and just N. of a fault, in Austin, Travis County, Texas. Collected July, 1940.

Locality 96. Georgetown Formation, along Smith Branch, the first main creek $E$. of the town of Georgetown, in an exposure for about $1.2 \mathrm{~km}$, N.E. of Texas highway 104, Williamson County, Texas. Collected July, 1940.

Locality 97. Main Street Formation, just E. of the Santa
Fe railroad underpass, on the Belton-Temple highway (U.S. highway 81), N.E. of Belton, Bell County, Texas. Collected July, 1940.

Locality 99. Denton Formation, in a roadside ditch on E. side of road leading $\mathrm{S}$. from Rio Vista, on N.E. corner where a minor $E$. branch road turns from the main $S$. road, $1.6 \mathrm{~km} \mathrm{~S}$. of the garage and filling station near the E. edge of Rio Vista town, in southern Johnson County, Texas. Collected July, 1940.

Locality 104. Duck Creck Formation, in a high, N.-facing slope on S. bank of Red River, cleared by excavation at the site of the Denison Dam that forms Lake Texhoma. N. of Denison, Grayson County, Texas. Collected July. 1940.

Locality 169. Goodland Formation, in a low bluff on E. bank of N. Fork of Mary's Creck at a concrete bridge on the Fort Worth-Weatherford highway, $18.4 \mathrm{~km} \mathrm{W.} \mathrm{of}$ Fort Worth, Tarrant County, Texas. Collected August 12, 1941.

Locality 172. Goodland Formation, in a low, N.-facing bluff on S. bank of Clear Creek, $0.3 \mathrm{~km} \mathrm{~W}$. of bridge of Farm Road 425 across Clear Creek, $7.8 \mathrm{~km} \mathrm{W.} \mathrm{of} \mathrm{U.S.}$ highway 77 junction with the farm road in Sanger. Denton County, Texas. Collected August, 1941.

Locality 203. Weno Formation, in a road cut on E. side of Old Mansficld Road, $0.4 \mathrm{~km} \mathrm{~S}$. of bridge over Sycamore Creek, W. of Glen Garden Country Club, $4.8 \mathrm{~km}$ S.E. of Fort Worth, Tarrant County, Texas. Collected October, 1943.

Locality 206. Denton Formation, in an intermittent

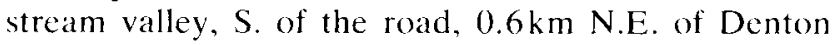
Creek, $2.6 \mathrm{~km}$ E. of Justin-Ponder road in Justin, Denton County, Texas. Collected October, 1943.

Locality 248. Goodland Formation, at Lake Worth Dam, in Fort Worth, Tarrant County, Texas. Collected July, 1948.

Sample 1026. Paw Paw Formation, in an exposure along a N.-flowing tributary to Clear Creck, $0.8 \mathrm{~km}$ E. of road, $6.8 \mathrm{~km}$ due N. of town square in Denton, Denton County, Texas. Collected August. 1949.

Subsurface Maness Formation from Shell Oil Company S.T. Stephens No. 1, LaRuc area, Henderson County, Texas. The Maness Formation was cored from 3600 to 3665 feet in depth.

Atlantic Deep Sea Core A $167-25$, a $175 \mathrm{~cm}$ core at a water depth of $1745 \mathrm{~m}$ from the Blake escarpment, at $28^{\circ} 52^{\prime} \mathrm{N}$. Lat., $76^{\circ} 47^{\prime} \mathrm{W}$. Long. This material was dated by A.R. Loeblich, Jr. as Cenomanian, and slightly younger than the surface Washita Group of Texas and Oklahoma (Ericson et al. 1961, p. 236).

All types and figured specimens are deposited in the U.S. National Museum, Washington, D.C. 


\section{Systematic Descriptions}

Order Foraminiferida Eichwald, 1830

Suborder Textulariina Delage \& Hérouard, 1896

Superfamily Lituolacea de Blainville, 1825

Family Spiroplectamminidae Cushman, 1927

1927 Spiroplectammininae Cushman:21

1981 Spiroplectamminidae; nom. transl. Saidova: 19 (ex subfamily Spiroplectammininac Cushman, 1927:21).

1981 Spiroplectamminidea; nom. transl. Saidova: 19 (ex subfamily Spiroplectammininae Cushman. 1927:21) [supcrfamily].

1981 Spiroplectammininea; nom. transl. Saidova: 19 (ex subfamily Spiroplectammininae Cushman, 1927:21) [supersubfamily].

Remarks. The subfamily was elevated to family status by Saidova (1981) who also recognized the superfamily Spiroplectamminidea for taxa with simple walls (in contrast to the Tawitawiidea, with internal pillars), but included within it the families Spiroplectamminidae, Textulariidae, Plectorecurvoididae, Morulaeplectidae, and Nouriidae. As all family group taxa are of equivalent status for purposes of priority, the family group name Textulariidae Ehrenberg, 1838 has priority for superfamily status. The family Spiroplectamminidae was stated (Saidova, 1981) to have a planispiral early stage, followed by a biserial or straight uniserial stage. Banner \& Pereira (1981) also defined the family as having an initial planispire and later biserial stage, but lacking a terminal uniserial stage. It is also characterized by a solid wall. without canaliculi or pseudopores. Although Semivulvulina, which possesses these structures, was thought to have evolved from Spirorutilis in the Eocene, and was included by Banner \& Pereira in the Spiroplectamminidae pending further study, we would restrict the family to include only those taxa with solid walls. In addition to Spiroplectammina Cushman, 1927 and Spirorutilis Hofker, 1976, the new genera Heterantyx and Quasispiroplectammina are here placed in the family Spiroplectamminidae.

\section{Genus Heterantyx gen. nov.}

Type species. Heterantyx antonovae sp. nov. Derivation of name. Greek heteros, different + antyx, edge, rim. Gender feminine.

Diagnosis. Genus of Spiroplectamminidac having a lozenge-shaped cross-section of truncated margins, with prominent median ridge at the junction of the two series of chambers and with ridges at each angle of the test. Description. Test free, with lozenge-shaped crosssection and truncated margins, early stage coiled in the plane of the later biserial chambers; sutures commonly limbate, zigzag suture may form prominent median ridge, commonly angles of test also prominently ridged lengthwise; wall finely agglutinated, solid and noncanaliculate; aperture slit-like or may form a low arch at base of final chamber face.

Remarks. Heterantyx is similar in some respects to Tetragonostomina Mikhalevich (1975, p. 86) in having strongly limbate sutures, an elevated median ridge on the test, and in the test being laterally truncated at least for the last pair of chambers, but the latter genus differs in increasing more rapidly in size with growth, in lacking the truncated test margins for its entire length, is biserial throughout, and has a rimmed quadrangular aperture.

In addition to the type species, this genus includes $H$. rectangularis (ten Dam), formerly Spiroplectammina rectangularis ten Dam, 1947 , and $\boldsymbol{H}$. cretosa (ten Dam). formerly Spiroplectammina rectangularis var. cretosa ten Dam, 1950, both from the Albian of the Netherlands, and H. magna (Antonova \& Kalugina), formerly Spiroplectammina magna Antonova \& Kalugina, 1964, from the Barremian of the Krasnodar area.

\section{Heterantyx antonovae sp. nov.} (Pl. 1, figs. 1-5)

Derivation of name. After Z.A. Antonova, Krasnodar, U.S.S.R.

Diagnosis. Species of Heterantyx having a lozengeshaped cross-section, truncated at the margins, with prominent, straight, elevated zigzag ridge and limbate and elevated sutures.

Holotype. Specimen of PI. 1, figs. 3, 4.

Material. Figured paratypes, and several hundred unfigured specimens.

Locality and horizon: Holotype and paratype (fig. 5) from the Georgetown Formation in a "Gryphaea" agglomerate at a concrete ford, $1.8 \mathrm{~m}$. above base exposed, locality 96. Paratype (figs. 1,2) and unfigured paratypes from the Goodland Formation in a massive chalky limestone about $13 \mathrm{~m}$ below top of exposure at locality 248. Other specimens were studied from the Goodland, Georgetown and Denton Formations.

Description. Test free, with a lozenge-shaped crosssection having the margins truncated and the angles with prominent ridges, early chambers in a small planispiral coil. commonly with four chambers surrounding the proloculus before the first pair of biserial chambers, biserial chambers increasing gradually in size as added; sutures straight, strongly limbate and elevated, zigzag suture forms a median ridge, more elevated than the lateral sutures, extending from just above the proloculus to die out just below the final two pairs of biserial chambers; wall very finely agglutinated, surface fincly granular in appearance in the optical microscope; aperture a low slit at the base of the last formed chamber.

Dimensions. Holotype, length $0.38 \mathrm{~mm}$, width $0.21 \mathrm{~mm}$, thickness $0.13 \mathrm{~mm}$; paratype of fig. 5 , length $0.30 \mathrm{~mm}$., width $0.18 \mathrm{~mm}$, thickness $0.13 \mathrm{~mm}$; paratype of figs. 1,2 , 


\section{Explanation of Plate 1}

All figures are $\mathrm{x} 100$.

Figs. 1-5. Heterantyx antonovae sp. nov.: figs. 1, 2, paratype, side and top views, Goodland Formation, locality 248; figs. 3, 4, holotype, side and top views, Georgetown Formation, locality 96; fig. 5, paratype, side view, Georgetown Formation, locality 96 . Note truncated margins, limbate suture, small initial coil, and median ridge on each face of the test as well as at each of the four angles.

Figs. 6-10. Quasispiroplectammina nuda (Lalicker): fig. 6, large hypotype, Main Street Formation, locality 97; fig. 7, hypotype, Grayson Formation, locality 1; fig. 8, hypotype, Duck Creek Formation, locality 104; figs. 9, 10 , hypotype, side and top views, Fort Worth Formation, locality 48 . Note small planispiral coil, very prominent limbate and elevated sutures of biscrial stage that tend to project beyond the chambers at the test margins, and ovate top view, with subacute lateral margins.

Figs. 11-17. Quasispiroplectammina alexanderi (Lalicker): fig. 11, 12, hypotype, Weno Formation, locality 203, side and edge views to show flattened early stage and inflated chambers of later part; fig. 13, hypotype, Maness Formation, Shell S.T. Stephens No. 1; figs. 14, 15, hypotype, Denton Formation, locality 99, side and top views to show nearly circular section; fig. 16, hypotype, Fort Worth Formation, locality 44; fig. 17, hypotype, Goodland Formation, locality 169.

Figs. 18-22. Bimonilina reciprocata sp. nov: fig. 18, paratype; figs. 19, 20, paratype, side and top views; both from Weno Formation, locality 203; figs. 21, 22, holotype, Fort Worth Formation, locality 44. Note twisted, loosely biserial test and slitlike areal aperture.

Figs. 23-36. Quasispiroplectammina longa (Lalicker): fig. 23, hypotype, Duck Creek Formation, locality 57; fig. 24, hypotype, Fort Worth Formation, locality 56; figs. 25, 26, hypotype, side and top views, Main Street Formation, locality 36. Note inflated chambers, constricted sutures, and gradually enlarging test.

Figs. 27-30. Spiroplectammina ammovitrea Tappan: figs. 27, 30, hypotypes, Paw Paw Formation, sample 1026; figs. 28, 29, hypotype, Grayson Formation, locality 1, side and top views. Note large multichambered planispiral coil followed by biserial portion of lesser breadth, as typical of true Spiroplectammina.

Figs. 31-33. Quasispiroplectammina goodlandana (Lalicker): fig. 31, hypotype, Goodland Formation, locality 172; figs. 32. 33, side and top views of same specimen. Note tiny planispire followed by flaring biserial portion, ovate cross section and rounded margins. 


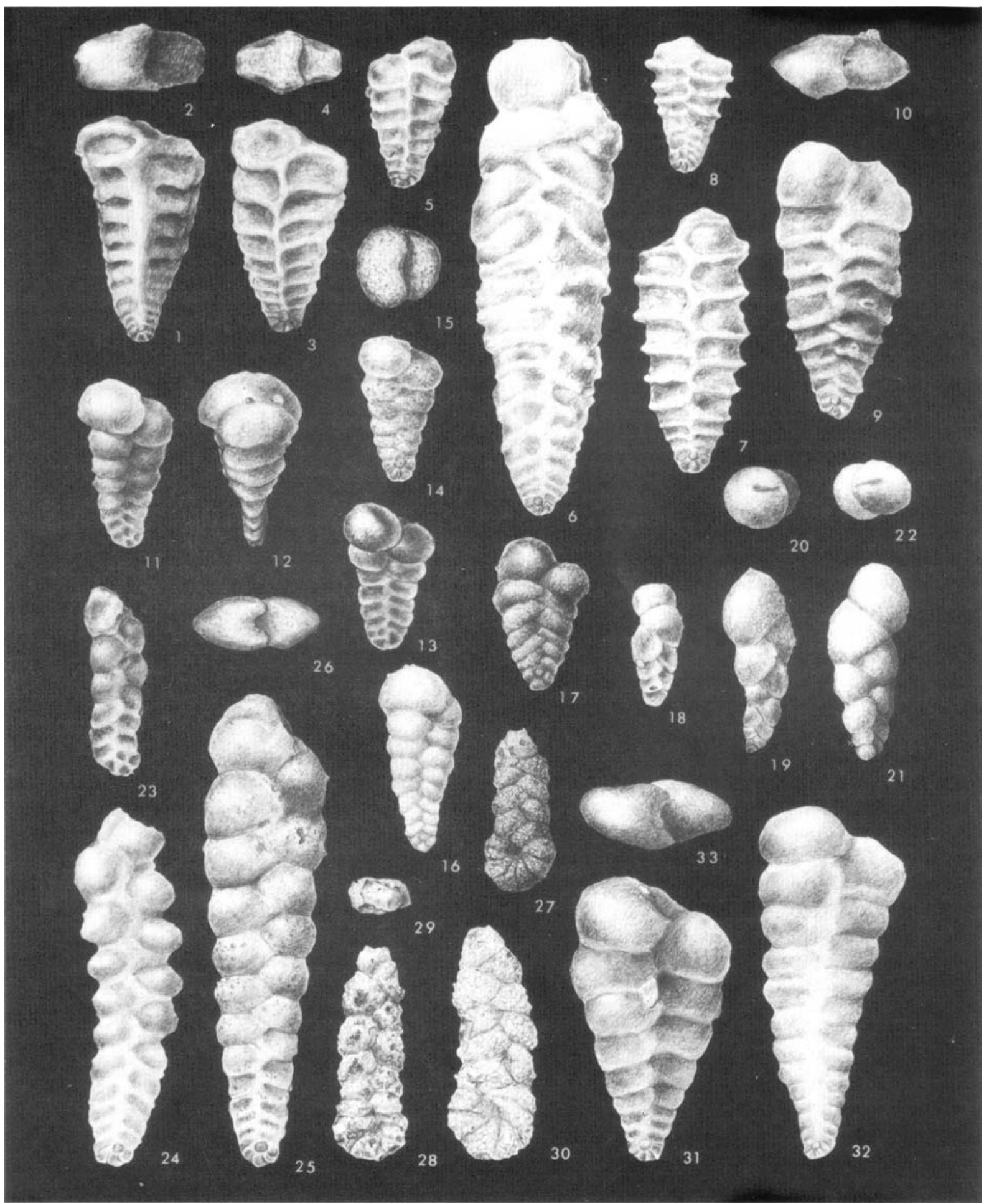


length $0.35 \mathrm{~mm}$, width $0.23 \mathrm{~mm}$, thickness $0.14 \mathrm{~mm}$. Max. length of other specimens $0.56 \mathrm{~mm}$, max. width $0.30 \mathrm{~mm}$ and max. thickness $0.16 \mathrm{~mm}$.

Remarks: Heterantyx antonovae sp. nov. resembles Spiroplectammina magna Antonova \& Kalugina in Antonova, Shmygina, Gnedina \& Kalugina (1964, p. 34 , pl. 4 , figs. 4,5 ), but differs in having a more prominent and elevated zigzag suture that extends upward from just above the planispiral coil to disappear on the final two pair of biserial chambers. The Texas species is slightly larger, as the maximum measurements of the Russian species are $0.45 \mathrm{~mm}$ length, 0.50 width. and $0.22 \mathrm{~mm}$ in thickness. $H$. antonovae differs from $H$. rectangularis (ten Dam) and $H$. cretosa (ten Dam) in having fewer chambers in the early coil (five instead of 8-9) and in enlarging more rapidly with growth, in the lozenge-shaped cross-section, truncate margins and the straight and prominent median ridge terminating just below the last two pair of chambers.

\section{Genus Quasispiroplectammina gen. nov.}

Type species. Quasispiroplectammina nuda (Lalicker) - Spiroplectammina nuda Lalicker, 1935.

Derivation of name. Latin quasi-, appearing like, simulating + Spiroplectammina, a genus of foraminifers. Diagnosis. Genus of Spiroplectamminidae that shows a growth pattern of gradual chamber size increase, producing a test that is intermediate in form between Spiroplectammina and Spirorutilis, a small coiled stage being followed by a later gradually enlarging biserial stage with an ovate or rarely circular cross-section.

Description. Test free, increasing gradually in size, the carly planispiral coil being smaller than the succeeding biscrial stage. and in the same plane as the biserial chambers; test oval to broadly ovate in section or ovate to nearly circular depending on growth pattern; wall thin, very finely agglutinated, to almost appear hyaline, of calcareous to siliceous particles, test disintegrates in $\mathrm{HCl}$, half-sections in SEM show the wall to be solid and noncanaliculate; aperture a low arch at the base of the last formed chamber.

Remarks. Quasispiroplectammina gen. nov. differs from Spiroplectammina in having an early coil that is of lesser diameter than the following gradually enlarging biserial portion, whereas in Spiroplectammina the coil is larger. Quasispiroplectammina is soluble in $\mathrm{HCl}$ as is the type species of Spiroplectammina although some fossil species of the latter are insoluble. It differs from Spirorutilis in having an oval to circular cross-section rather than being flattened to diamond-shaped in section.

Quasispiroplectammina alexanderi (Lalicker, 1935) (Pl. 1, figs. 11-17)

1935 Spiroplectammina alexanderi Lalicker: 1, pl. 1, figs. 1 a-c. non 1980 Textularia alexanderi (Lalicker); Haig: 112 , pl. 5, figs. 1-4.

Material. Several hundred specimens.

Locality and horizon. Figured hypotype (figs. 11, 12) from the Weno Formation from a $30 \mathrm{~cm}$ marl below a heavy limestone, about $4.8 \mathrm{~m}$ below the upper heavy limestone of the formation at locality 203. Figured hypotype (fig. 13) from the Maness Formation from mid portion of core at 3635-3665 feet, Shell S.T. Stephens No. 1. Figured hypotype (figs. 14, 15) from the Denton Formation, upper $1.6 \mathrm{~m}$ of the formation, locality 99. Figured hypotype (fig. 16) from the Fort Worth Formation, in about an $80 \mathrm{~cm}$ section of shaly marls and limestones at locality 44. Figured hypotype (fig. 17) from the Goodland Formation in the middle $1.5 \mathrm{~m}$ of blue gray clay exposed, about $1.5 \mathrm{~m}$ above the creek bed at locality 169. Other specimens were studied from the Walnut Formation and Goodland Formation (Fredericksburg Group) and the Duck Creek, Fort Worth, Denton, Main Strect, Georgetown and Del Rio Formations (Washita Group) at various localitics in Texas and Oklahoma.

Remarks. Half sections examined under the SEM show the walls to be solid and noncanaliculate. Specimens also dissolve readily in $\mathrm{HCl}$. Haig (1980, p. 112) transferred this species to Textularia as he interpreted the figure of the holotype as having "3 exposed chambers" in the early coil. Although the original figures do not show the basal coil clearly, every specimen of the species examined by us shows a well-developed early coil of $4-5$ chambers. Haig's Quecnsland specimens show only occasional incipient coiling, the majority being biserial throughout. In addition, the Queensland specimens do not show a flattened and compressed early stage with oval outline and the rapidly expanding later chambers to produce a nearly circular outline as seen from above in $Q$. alexanderi. Thus Haig's specimens are not conspecific with $Q$. alexanderi.

Quasispiroplectammina goodlandana (Lalicker, 1935) (PI. 1. figs. 31-33)

1935 Spiroplectammina goodlandana Lalicker: 2. pl. 1. figs. 2-3.

Material. Several hundred specimens.

Locality and horizon. Figured hypotypes (figs. 31-33) from the Goodland Formation, in a $60 \mathrm{~cm}$ dark gray marl between heavy bedded white and nodular limestones, about $30 \mathrm{~cm}$ above the creek water level at locality 172 . Numerous additional specimens are from the Goodland Formation at localities 73, 172, 248 and from the Walnut Formation of Oklahoma.

Remarks. Study of half-sectioned specimens in SEM shows the wall of this species to be solid and noncanaliculate. The test disintegrates completely in $\mathrm{HCl}$, and consists of agglutinated calcareous particles. 
Quasispiroplectammina longa (Lalicker, 1935)

(Pl. 1, figs. 23-26)

1935 Spiroplectammina longa Lalicker: 3, pl. 1, figs. 4. 5 .

Material. Several thousand specimens from the Fredericksburg and Washita Groups.

Locality and horizon. Figured hypotype (fig. 23) from the Duck Creek Formation, in a $1.8 \mathrm{~m}$ section of interbedded yellow-gray marls and limes just below a $60 \mathrm{~cm}$ limestone bed, about $3 \mathrm{~m}$ above base exposed at locality 57. Figured hypotype (fig. 24) from the Fort Worth Formation, in the lowest exposed $3 \mathrm{~m}$ of marl with a few thin limestone beds, at locality 56 . Figured hypotype (figs. 25, 26) from the Main Street Formation in a $1.6 \mathrm{~m}$ section of nodular limes and marls $4 \mathrm{~m}$ above the base of the formation at locality 36 . Other specimens are from the Kiamichi Formation (Fredericksburg Group) and Duck Creek, Fort Worth, Denton. Weno, Paw Paw, Main Street, Grayson. Georgetown, Del Rio and Maness Formations (Washita Group) of Oklahoma and Texas.

Remarks. The thin and smoothly polished agglutinated wall consists of calcarcous particles, readily dissolving in acid, leaving only a small quantity of organic material. In SEM, half-sections show the thin wall to be solid and noncanaliculate.

\section{Quasispiroplectammina nuda (Lalicker, 1935)}

$$
\text { (Pl. 1, figs. 6-10) }
$$

1935 Spiroplectammina nuda Lalicker:4, pl. 1, figs. 6, 7.

Material. Several hundred specimens.

Locality and horizon. Figured hypotype (fig. 6) from the Main Street Formation in a $1.5 \mathrm{~m}$ section of marls intercalated between limestone ledges at locality 97. Figured hypotype (fig. 7) from the Grayson Formation, $8.3 \mathrm{~m}$ below top of exposure in a $9 \mathrm{~cm}$ nodular zone at locality 1. Figured hypotype (fig. 8) from the Duck Creek Formation in a $2.5 \mathrm{~m}$ section of blue clay, beginning $10.8 \mathrm{~m}$ above the base of the formation at locality 104 . Figured hypotype (figs. 9, 10) from the Fort Worth Formation, in the top $3.3 \mathrm{~m}$ of alternating limestones and light yellow marls at locality 48 . Numerous other specimens are from the Duck Creek, Fort Worth, Denton, Weno, Paw Paw, Main Street, Grayson, Maness, Georgetown and Del Rio Formations from Oklahoma and Texas.

Remarks. This distinctive species with sharply elevated and limbate sutures has a wall of fine grained agglutinated carbonate grains that disintegrate in acid to leave only an organic film. In half-section under SEM the wall is seen to be solid and noncanaliculate.

Genus Spiroplectammina Cushman, 1927

1927 Spiroplectammina Cushman: 23
Type species. Spiroplectammina biformis (Parker \& Jones) $=$ Textularia agglutinans d'Orbigny var. biformis Parker \& Jones, 1865:370.

Remarks. Spiroplectammina was restricted by Hofker (1976) and redefined by Banner \& Pereira (1981) to include only those species with solid wall, lacking canaliculi and pseudopores, with large initial planispiral coil followed by a biserial stage of lesser width than the coil, and an uncompressed test with ovoid cross-section. Some species previously included in Spiroplectammina were transferred to Spirorutilis Hofker, which has a biserial stage broader than the early coil, and a laterally compressed test commonly rhombic in section and. in the type species, with a sharply angled to subcarinate periphery. True Spiroplectammina is present in the Texas mid Cretaccous, as well as those species we have transferred to Quasispiroplectammina gen. nov. No specimens in our material of this age are referable to Spirorutilis, however.

Spiroplectammina ammovitrea Tappan, 1940

(Pl. 1, figs. 27-30)

1940 Spiroplectammina ammovitrea Tappan:97, pl. 14, figs. $13 \mathrm{a}, \mathrm{b}$.

Material. Approximately 100 specimens.

Locality and horizon. Figured hypotypes (figs. 27, 30) from the Paw Paw Formation in $1.8 \mathrm{~m}$ section beginning about $1.6 \mathrm{~m}$ above the base of the formation, in Sample 1026. Figured hypotype (figs. 28, 29) from the Grayson Formation, $6.9 \mathrm{~m}$ below the top of the formation at locality 1. It has been reported from the Duck Creek Formation (Tappan, 1943) and also occurs in the Weno, Paw Paw, Grayson and Del Rio Formations elsewhere in Oklahoma and Texas.

Remarks. S. ammovitrea is a true Spiroplectammina, with large initial planispire, followed by nearly parallel sided narrow biserial portion and with a solid, noncanaliculate wall as seen in SEM observation of half sectioned specimens. It is insoluble in $\mathrm{HCl}$.

Family Textulariopsidae fam. nov.

Type genus. Textulariopsis Banner \& Pereira, 1981. Diagnosis. Frec-living foraminifers with early biserial stage, or may have a single adventitious chamber producing a pseudotriserial base; later stage may be biserial, loosely biserial or uniserial; wall agglutinated, solid and noncanaliculate.

Description. Test free, early stage biserial, or with a single adventitious chamber resulting in a pseudotriserial arrangement at the base, later biserial stage may be slightly twisted, final stage may become loosely biserial or completely uniserial; aperture in the biserial stage an arch at the base of the final chamber, and may become slit-like in the face, to terminal in the final stage. Wall 
agglutinated, solid and noncanaliculate, may consist of calcareous or siliceous particles, held in a calcareous cement (disintegrating in $\mathrm{HCl}$ ) or held in an organic cement and insoluble in $\mathrm{HCl}$ (Aaptotoichus).

Horizon. As far as known, the family occurs from Lower Jurassic (Pliensbachian) to Upper Cretaceous (Maastrichtian).

Remarks. The genera Textulariopsis and Plectinella were placed in the subfamily Verneuilininae of the family Ataxophragmiidae by Banner \& Pereira (1981), on the basis of the solid, noncanaliculate wall, in contrast to the Textulariidae, which appear to be largely Cenozoic in age and to have a canaliculate agglutinated wall. The group of genera here placed in the Textulariopsidae differ from the Ataxophragmiidae in being biserial in the early stage, or with a single adventitious third chamber at the base, rather than having a distinct early triserial stage (Verneuilininae) or distinct early spire (Dorothiinae, Ataxophragmiinae). Six genera are here included: Bimonilina Eicher, 1960, Plectinella Marie, 1956 (=Arenovirgulina Said \& Barakat, 1958), Textulariopsis Banner \& Pereira, 1981, and three new genera described herein, Aaptotoichus, Haimasiella and Minyaichme.

\section{Genus Aaptotoichus gen. nov.}

Type species. Aaptotoichus clavellatus (Loeblich \& Tappan) $=$ Bigenerina clavellata Loeblich \&. Tappan, 1946.

Derivation of name. Greek aaptos, invincible + toichos, wall of house. Gender masculine.

Diagnosis. Test with short early biserial stage followed by a longer uniserial portion of broad low chambers, commonly compressed in preservation. Wall agglutinated, solid, without perforations, but thin and commonly deformed, insoluble in acid. Aperture terminal, rounded. Description. Test tiny, short biserial stage of rapidly enlarging broad low chambers followed by uniserially arranged chambers that are round in cross-section, but commonly compressed in preservation, and increase only slightly in diameter. Wall agglutinated, insoluble in $\mathrm{HCl}$, consisting of fine siliceous particles, solid and noncanaliculate. Aperture becoming terminal in the uniserial portion, small and rounded.

Remarks. Aaptotoichus differs from Bigenerina in having solid noncanaliculate walls, and in the smaller size (about $1 / 3$ that of the type species). It differs from both Bigenerina and Haimasiella gen. nov. in having a wall of organic material with siliceous particles, and is insoluble in $\mathrm{HCl}$.

In addition to the type species, Ammobaculoides pitmani Crespin = Bigenerina pitmani $($ Crespin) Haig, from the Aptian and Albian of Queensland and South Australia may belong to Aaptotoichus; the specimens referred to Bigenerina clavellata by Bartenstein \& Brand (1951, pl. 4, figs. 75, 76), although not this species, certainly do belong to Aaptotoichus. The genus ranges from Valanginian to early Cenomanian in age.

Aaptotoichus clavellatus (Loeblich \& Tappan, 1946)

(Pl. 2, figs. 1-7)

1946 Bigenerina clavellata Loeblich \& Tappan:245, pl. 35 , figs. 7,8 .

non 1951 Bigenerina clavellata Loeblich \& Tappan; Bartenstein \& Brand:275, pl. 4, figs. 75, 76.

non 1966 Bigenerina cf. clavellata Loeblich \& Tappan; Bartenstein, Bettenstaedt, \& Bolli:141, pl. 1, figs. 60-63.

non 1973 Bigenerina clavellata Loeblich \& Tappan; Bartenstein \& Bolli:395, pl. 1, figs. 22, 23.

Material. Some hundreds of specimens from the Denton, Weno, and Paw Paw Formations, where it is most abundant.

Locality and horizon. Figured hypotypes (figs. 1, 4) from the Maness Formation from mid portion of core at 3635-3665 feet, in Shell S.T. Stephens No. 1. Figured hypotypes (figs. 2, 3, 5) from the Paw Paw Formation, $1.8 \mathrm{~m}$ above base of exposure on south side of road, in reddish and yellowish clay at locality 55 . Figured hypotype (fig. 6) from the Weno Formation in $80 \mathrm{~cm}$ section of alternating limestones, light grey marls and yellow and brown clays, about $80 \mathrm{~cm}$ above base of formation at contact with the underlying Denton Formation, locality 47. Figured hypotype (fig. 7) from the Paw Paw Formation from the upper $1.2 \mathrm{~m}$ exposed of fissile blue grey shales at locality 40 . Other specimens from the Denton, Weno, Paw Paw, Georgetown, Del Rio and Maness Formations.

Remarks. A. clavellatus is a tiny species, ranging from 0.28 to $0.86 \mathrm{~mm}$ in length. The possibly congeneric Ammobaculoides pitmani Crespin of Australia is about twice as large, ranging from 0.48 to $1.68 \mathrm{~mm}$ in length. Specimens referred to Bigenerina clavellata from the German Valanginian (Bartenstein \& Brand, 1951, pl. 4, figs. 75,76 ) appear to be a distinct species, with a much longer biserial stage. Specimens figured by Bartenstein, Bettenstaedt \& Bolli (1966, pl. 1, figs. 60-63) as Bigenerina cf. clavellata and by Bartenstein \& Bolli (1973, pl. 1, figs. 22, 23) as $B$. clavellata have chambers that are larger than in typical $A$. clavellatus and do not show the sharp junction between the distinct and unmistakably biserial portion and the following uniserial portion. Bartenstein \& Bolli (1973, p. 395) cite Orthokarstenia shastaensis Dailey 1970 as a synonym of Bigenerina clavellata, but this is incorrect as Dailey's species is a calcareous hyaline one having no relation to Aaptotoichus clavellatus.

Genus Bimonilina Eicher, 1960

1960 Bimonilina Eicher: 65.

1964 Pseudobolivina Wiesner; Loeblich \& Tappan in 
Moore (partim, non Wiesner 1931): C255, fig. $167(5,6)$.

Type species. Bimonilina varians Eicher, 1960.

Remarks. Bimonilina was described for a Lower Cretaceous species from Wyoming with slightly twisted biserial test and slitlike terminal aperture. Loeblich \& Tappan in Moore (1964) regarded Bimonilina Eicher, 1960, Plectinella Marie, 1956 and Arenovirgulina Said $\&$ Barakat, 1958 all as congeneric with Recent $P$ seudobolivina Wiesner, 1931. Based on their study of wall characters, Banner \& Pereira (1981, p. 100) reinstated Plectinella, which they regard as closely related to Textulariopsis and quite distinct from the Quaternary Pseudobolivina with thick chitinoid endoskeleton. We concur in this separation but, in addition, separate Bimonilina from both Plectinella and Pseudobolivina. It differs from Pseudobolivina in possessing a firm agglutinated wall, rather than a thinly agglutinated wall on a thick chitinoid endoskeleton, and from Plectinella in its more slender form, twisted growth and distinctly terminal aperture. A new species of Bimonilina is described herein from the Texas section. Bimonilina ranges from Albian to Cenomanian.

\section{Bimonilina reciprocata $\mathrm{sp}$. nov.}

(PI. 1, figs. 18-22)

Derivation of name. Latin, reciproco, -atus, return, move back and forth, alternate, with reference to the loosely biserial chamber arrangement of this species.

Diagnosis. A compact species of the genus Bimonilina having a greater tendency to become uniserial, in that the latest chambers overlap only one of the preceding biserial pair.

Material. 45 specimens.

Locality and horizon. Holotype (figs. 21, 22) from the Fort Worth Formation in a 80 to $90 \mathrm{~cm}$ section of yellowish and greyish shaly marls alternating with limestone beds at locality 44 . Figured paratypes (figs. 18-20) from the Weno Formation from a $30 \mathrm{~cm}$ marl beneath a heavy limestone about $5 \mathrm{~m}$ below the upper heavy limestone of the formation at locality 203. Other specimens are from the Fort Worth, Denton and Weno Formations at other Texas localities.

Description. Test free, small, elongate, biserial throughout, loosely so in the later stages, slightly twisted during growth, each new chamber formed overlaps both of the preceding biserial pair and appears to be a terminal uniserial chamber, rarely a terminal chamber touches only one of the preceding pair; chambers inflated, increase slowly in width, but rapidly in height; sutures depressed, wall thin, finely agglutinated, rather smoothly finished; aperture an elongate slit, areal in position and terminal on the final chamber.

Dimensions. Holotype $0.38 \mathrm{~mm}$ in length, $0.16 \mathrm{~mm}$ max. width, $0.10 \mathrm{~mm}$ thickness; paratypes $0.35 \mathrm{~mm}$ in length,
$0.14 \mathrm{~mm}$ in width, $0.13 \mathrm{~mm}$ in thickness and $0.23 \mathrm{~mm}$ in length, $0.08 \mathrm{~mm}$ in width and 0.06 in thickness.

Remarks. $B$. reciprocata sp. nov. differs from $B$. variana Eicher in being more compact and in being less tapering, less compressed and in tending more toward a truly uniserial development.

\section{Genus Haimasiella gen. nov.}

Type species. Haimasiella wintoni (Cushman \& Alexander $)=$ Bigenerina wintoni Cushman \& Alexander, 1930.

Derivation of name. Greek, haimasia, wall of stones + ella, diminutive. Gender feminine.

Diagnosis. Elongate compressed biserial early stage, abruptly changing to a uniserial portion with cylindrical uncompressed chambers; wall solid, agglutinated of calcareous particles, dissolving in $\mathrm{HCl}$; aperture terminal, rounded.

Description. Test with an elongate compressed biserial early stage having flattened sides and truncated margins, changing abruptly to the later long uniserial portion of cylindrical chambers. Sutures straight, oblique and thickened in early stage, horizontal and depressed in uniserial portion. Wall solid, noncanaliculate, agglutinated of mostly calcareous particles, disintegrating in $\mathrm{HCl}$. Aperture terminal, rounded.

Remarks. Haimasiella nov. gen. differs from Bigenerina in having a solid, noncanaliculate wall and from Aaptotoichus gen. nov. in not having an acid resistant wall.

Haimasiella wintoni (Cushman \& Alexander, 1930) (Pl. 2, figs. 20-25)

1930 Bigenerina wintoni Cushman \& Alexander:9, pl. 2, figs. $15 \mathrm{a}, \mathrm{b}$.

non 1940 Bigenerina wintoni Cushman \& Alexander; Tappan:99, pl. 15, figs. 5a, b.

Material. Several hundred specimens.

Locality and horizon. Figured hypotype (fig. 20) from the Duck Creek Formation, $2 \mathrm{~m}$ section of alternating shales and limestones, $8.25 \mathrm{~m}$ above the base of the formation at locality 104 . Figured hypotypes (figs. 24, 25 ) from the Duck Creek Formation in a $2.5 \mathrm{~m}$ section of laminated blue grey marly clays becoming more limy at the base, $5.8 \mathrm{~m}$ above the base of the formation at locality 104. Figured hypotype (fig. 21) from the Fort Worth Formation from the lower $0.5 \mathrm{~m}$ exposed of yellowish and grey marls and marly limestones at locality 39. Figured hypotypes (figs. 22, 23) from the Denton Formation in the basal $1.2 \mathrm{~m}$ of reddish clay and thin iron-stained limestones just above the Fort Worth Formation at locality 206.

It occurs elsewhere in the Duck Creek, Fort Worth, Denton, Main Street, and Georgetown Formations.

Remarks: Specimens reported by Tappan (1940) as rare in the Grayson Formation appear to be aberrant 


\section{Explanation of Plate 2}

Figs. 1-7. Aaptotoichus clavellatus (Loeblich \& Tappan): figs. 1, 4, hypotypes, Maness Formation, Shell S.T. Stephens No. 1; figs. 2, 3, hypotype, side and top views; fig. 5, hypotype; both from the Paw Paw Formation, locality 55; fig. 6, hypotype, Weno Formation, locality 47; fig. 7, hypotype, Paw Paw Formation, locality 40. Note short, rapidly expanding biserial portion with inflated chambers, followed by uniserial stage of nearly constant breadth and short inflated chambers. (All x63.)

Figs. 8-10. Textulariopsis losangica (Loeblich \& Tappan): figs. 8,9, hypotype, side and top views; fig. 10, hypotype; both from the Duck Creek Formation, locality 13. Note development of median ridge on face of early part, and subacute margins, producing a lozenge-shaped section; the median ridge becomes less prominent in very large specimens on the later part. (All x63.).

Figs. 11-15. Textulariopsis lechriosa sp. nov.: figs. 11, 12, holotype, side and top views, Fort Worth Formation, locality 44; fig. 13, paratype; figs. 14, 15, paratype, side and edge views; both paratypes from the Fort Worth Formation, locality 44 . Note rapidly flaring test, broad, low chambers, strongly oblique sutures, and flattened test faces. (All x63.)

Figs. 16-19. Minyaichme duckcreekensis (Tappan): figs. 16, 17, hypotype, side and top views, Cenomanian, Atlantic deep sea core A 167-25; figs. 18, 19, hypotype, side and top views, Georgetown Formation, locality 96. Note flattened biserial chambers that increase rapidly in height, and terminal ovate aperture. (Figs. 16, 17, x63; figs. 18,19, x 100.).

Figs. 20-25. Haimasiella wintoni (Cushman \& Alexander): figs. 20,24,25, hypotypes, Duck Creek Formation, locality 104; fig. 21, hypotype, Fort Worth Formation, locality 39; figs. 22, 23, hypotype, side and top views, Denton Formation, locality 206. Note rapidly enlarging biserial stage with quadrate section resulting from flattened sides and truncate margins, followed abruptly by cylindrical uniserial portion of subglobular chambers, with round terminal aperture. (Figs. 20, 21-24, x48; fig. 25, x22.).

Figs. 26-28. Textulariopsis rioensis (Carsey): figs. 26, 27, hypotype, side and top views, Goodland Formation, locality 73; fig. 28, hypotype, Fort Worth Formation, locality 56. Note broad, inflated test, subcircular section, and variation in coarseness of agglutinated particles. (All x63.).

Figs. 29-31. Minyaichme subcretacea (Tappan): figs. 29, 30, hypotype, side and top views, Duck Creek Formation, locality 104; fig. 31, hypotype, Cenomanian, Atlantic deep sea core A 167-25. Note prominent ribs at test angles, giving a distinctly angular appearance to the biserial test, rapidly enlarging chambers in the early part, and the subterminal areal oval aperture. (Figs. 29, 30, x100; fig. 31, x63.).

Figs. 32-37. Textulariopsis washitensis (Carsey): figs. 32, 33, hypotype, side and top views, Del Rio Formation, locality 90; figs. 34, 35, hypotype, side and top views, Maness Formation, Shell S.T. Stephens No. 1; figs. 36, 37, hypotype, side and top views, Grayson Formation, locality 1 . Note large test, rapid increase in size in early stage, and later subparallel margins, depressed and slightly arched sutures, and flattened to ovate section. (All $x 44$.).

Figs. 38-39. Textulariopsis texhomensis sp. nov. Holotype, side and top views, Duck Creek Formation, locality 104. Note elongate narrow test, rounded to nearly subcircular in section, inflated chambers, and depressed sutures. (x63.). 


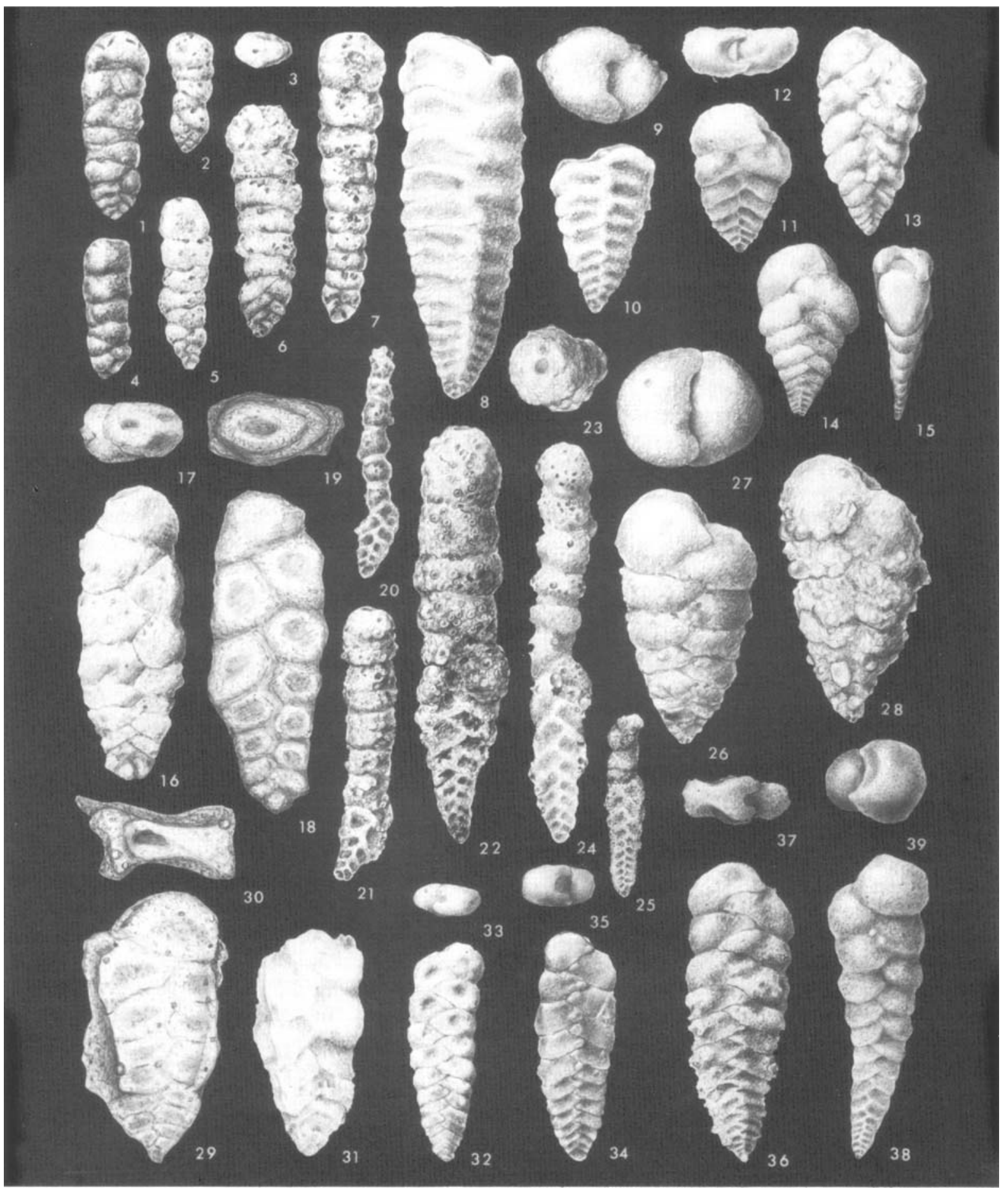


individuals of Textulariopsis washitensis with an occasional uniserial chamber and not true $H$. wintoni.

\section{Genus Minyaichme gen. nov.}

Type species. Minyaichme subcretacea (Tappan) = Siphotextularia subcretacea Tappan 1943.

Derivation of name. Greek, minys, small + aichme, point of a spear, with reference to the general test shape. Gender feminine.

Diagnosis. Test free, elongate, consisting of biserially arranged chambers enlarging gradually as added, rarely with a third adventitious chamber at the base giving a pseudotriserial appearance, sides flattened, angles rounded to acutely angled, commonly forming ridges that arise near the base. Wall solid, noncanaliculate, dissolves rapidly in $\mathrm{HCl}$. Aperture large, ovate, areal, subterminal to terminal in position.

Description. Test free, elongate, sides of test flattened to concave with angled to subrounded edges that may become prominent ridges at the four angles, relatively few chambers, biserially arranged and enlarging gradually as added, sutures nearly horizontal, only slightly depressed. Wall solid, noncanaliculate, thin, of whitish calcareous particles cemented together; aperture ovate, areal, subterminal to terminal on the final chamber.

Remarks. Species now referred to Minyaichme gen. nov., were previously placed in Siphotextularia or Textularia, but both of the latter genera are Cenozoic ones with canaliculate walls. In addition, the aperture of Minyaichme is areal and subterminal rather than at the base of the final chamber as in Textularia and is not produced on a neck as in Siphotextularia.

\section{Minyaichme duckcreekensis ('Tappan, 1943)}

$$
\text { (Pl. 2, figs. 16-19) }
$$

1943 Textularia duckcreekensis Tappan:486, pl. 78, figs. 10a-c.

Material. Fourteen specimens.

Locality and horizon. Figured hypotype (figs. 16,17) of Cenomanian age from depth $20 \mathrm{~cm}$ in the $175 \mathrm{~cm}$ Atlantic Deep Sea Core A167-25, on the Blake Escarpment. Figured hypotype (figs. 18, 19) and additional specimens from the Georgetown Formation, from a $1 \mathrm{~m}$ section just beneath a zone of numerous "Gryphaea" washitensis, about $1.5 \mathrm{~km}$ downstream from road at locality 96 . The species was originally described from the Duck Creek Formation in Grayson County, Texas.

Remarks. The species was originally referred to Textularia because of the biserial chamber arrangement, but the aperture was stated (Tappan, 1943, p. 486) to be "slightly elongate, apparently in the face of the lastformed chamber, rather than at its base." Both the character of the aperture and the solid rather than canaliculate wall, as indicated by SEM study of half- sectioned specimens, show this species to be generically distinct from Textularia. It differs from $M$. subcretacea (Tappan) in being more elongate, tapering, and flattened and in lacking the four distinct ridges at the angles of the test.

\section{Minyaichme subcretacea (Tappan, 1943)}

$$
\text { (Pl. 2, figs. 29-31) }
$$

1943 Siphotextularia subcretacea Tappan:486, pl. 78, figs. $11 \mathrm{a}-\mathrm{c}$.

Material. 123 specimens.

Locality and horizon. Figured hypotype (figs. 29, 30) from the Duck Creek Formation; $2.5 \mathrm{~m}$ section, of bluish grey clays intercalated with $15 \mathrm{~cm}$ nodular limestones, beginning about $3.5 \mathrm{~m}$ above the base of the formation at locality 104. Figured hypotype (fig. 31) from depth $90 \mathrm{~cm}$ in the $175 \mathrm{~cm}$ Atlantic Deep Sea Core A 167-25 on the Blake Escarpment. Unfigured specimens are from the Goodland, Duck Creek, Fort Worth, Main Street, Georgetown and Maness Formations.

Remarks. This species is typically biserial throughout but occasional specimens may have a third adventitious chamber at the base that gives a pseudotriserial appearance. Because of the biserial chamber arrangement and areal aperture this species was originally placed in Siphotextularia. However, Siphotextularia has a canaliculate wall, and the aperture is produced on a neck unlike the present species. The wall of the present species is solid and noncanaliculate as seen in SEM examination of half-sectioned specimens. The wall is thin, whitish in appearance and readily soluble in $\mathrm{HCl}$. The sharp angles at the four corners of the test sides give a distinctive appearance to this species.

Genus Plectinella Marie, 1956

1956 Plectinella Marie:B240.

1958 Arenovirgulina Said and Barakat:243.

1964 Pseudobolivina Wiesner; Loeblich \& Tappan in Moore (partim, non Wiesner, 1931):C255, fig. 167 (4).

Type species. Plectinella virgulinoides Marie 1956. Remarks. Plectinella was described by Marie from the Upper Cretaceous, but because of the irregular biserial chamber arrangement and areal aperture tending to become terminal, it was placed in the synonymy of Pseudobolivina by Loeblich \& Tappan in Moore (1964). We agree with the current recognition of Plectinella as distinct from the Recent $P$ seudobolivina as suggested by Banner \& Pereira (1981, p. 100), who further noted the relationship of Plectinella to Textulariopsis. As Arenovirgulina appears to be synonymous with Plectinella, the genus ranges from Jurassic (Callovian) through the Cretaceous (Maastrichtian). In addition to $P$. virgulinoides, $P$. aegyptica $($ Said $\&$ Barakat $)=$ Areno - 
virgulina aegyptica Said \& Barakat, 1958, and Plectinella textulariaeformis (Akimets) =Bimonilina textulariaeformis Akimets, 1966 from the Hauterivian-Barremian of Belorussia are here transferred to Plectinella. Pseudobolivina parvula Ludbrook, 1966 from the Aptian-Albian of South Australia probably belongs to Plectinella.

\section{Genus Textulariopsis Banner \& Pereira, 1981}

1981 Textulariopsis Banner \& Pereira:98.

Type species. Textulariopsis portsdownensis Banner \& Pereira 1981.

Remarks. Banner \& Pereira (1981) studied the wall structure of a variety of agglutinated species, and found that certain Cretaceous species previously referred to Textularia have a solid wall whereas typical Textularia has a canaliculate wall. They proposed the new genus Textulariopsis for those with solid walls, regarding these as closer to the Mesozoic Ataxophragmiidae than to the Cenozoic Textulariidae. Three Texas Lower Cretaceous species previously referred to Textularia are here transferred to Textulariopsis, and two new species are described. In addition to these Cretaceous taxa, Textularia areoplecta Tappan, 1955 from the Lower Jurassic (Pliensbachian-Toarcian) of northern Alaska is here transferred as Textulariopsis areoplecta (Tappan).

\section{Textulariopsis lechriosa sp. nov.}

(Pl. 2, figs. 11-15)

Derivation of name. Greek, lechrios, slanting, crosswise, with reference to the strongly sloping chambers.

Diagnosis. A species of Textulariopsis characterized by chambers gradually increasing in size with little inflation producing a test with essentially flat, rather broad sides and an oval cross-section; sutures directed downward at an angle of ca. $45^{\circ}$.

Holotype. Specimen on Pl. 2, figs. 11, 12.

Material. 67 specimens.

Locality and horizon. Holotype from the Fort Worth Formation in a $90 \mathrm{~cm}$ section of marl between two heavy limestone beds, $3 \mathrm{~m}$ above base of exposure at locality 56. Figured paratype (fig. 13) from the Fort Worth Formation from a $1 \mathrm{~m}$ section of dark grey and yellow shale just below a heavy limestone and $5.7 \mathrm{~m}$ above the base of the exposure at locality 9. Figured paratype (figs. 14, 15) from the Fort Worth Formation in $1.8 \mathrm{~m}$ section, beginning $1.8 \mathrm{~m}$ above the base of the exposure also at locality 9. Other unfigured specimens are from the Fort Worth and Weno Formations.

Description. Test free, biserial, subpyramidal in outline, flattened ovate in section; chambers increasing gradually in height and length as added, with little inflation and a slow increase in test thickness producing nearly flat sides; sutures slightly depressed and directed downward from the median juncture at an angle of ca. $45^{\circ}$; wall finely agglutinated; aperture a low slit at the base of the final chamber.

Dimensions. Holotype length $0.45 \mathrm{~mm}$, width $0.30 \mathrm{~mm}$, thickness $0.15 \mathrm{~mm}$; paratype (fig. 13) length $0.61 \mathrm{~mm}$, width $0.31 \mathrm{~mm}$, thickness $0.10 \mathrm{~mm}$; paratype (figs. 14 , 15) length $0.5 \mathrm{~mm}$, width $0.30 \mathrm{~mm}$ and thickness $0.11 \mathrm{~mm}$.

Remarks. This species is similar to Textularia hybrida Chapman, 1899 but is about one half as large, increases more rapidly in width, and also increases slowly in thickness rather than being of identical thickness throughout.

\section{Textulariopsis losangica (Loeblich \& Tappan, 1951)}

(Pl. 2, figs. 8-10)

1951 Textularia losangica Loeblich \& Tappan in Lozo: 82 , pl. 2, figs. 4,5 .

Material. Several thousand specimens.

Locality and horizon. Figured hypotype (figs. 8, 9) from the Duck Creek Formation in a $1.6 \mathrm{~m}$ section of blue grey shale, $12.15 \mathrm{~m}$ below the top of the formation, at locality 13. Figured hypotype (fig. 10) from a $1.6 \mathrm{~m}$ section, just above the previous one at locality 13 . Unfigured specimens are from the Duck Creek, Fort Worth, Denton, Paw Paw, Georgetown and Maness Formations.

Remarks. This species is characterized by an angular periphery and raised zigzag suture between the two series of chambers, resulting in a diamond-shaped crosssection. The test may flare rapidly in the early stage, but in the very large specimens the later stage may have nearly parallel sides, the chambers increasing little if any in size as added. The wall is solid, noncanaliculate and of agglutinated calcareous material completely disintegrating in $\mathrm{HCl}$.

\section{Textulariopsis rioensis (Carsey, 1926)}

$$
\text { (Pl. 2, figs. 26-28) }
$$

1926 Textularia rioensis Carsey:24, pl. 7, fig. 12.

Material. Several thousand specimens.

Locality and horizon. Figured hypotype (figs. 26, 27) from the Goodland Formation in a $90 \mathrm{~cm}$ section of yellow grey marl, about $30 \mathrm{~cm}$ above the road level at locality 73 . Figured hypotype (fig. 28) from the Fort Worth Formation in a $90 \mathrm{~cm}$ section of marl between heavy limestone beds, $3 \mathrm{~m}$ above the base of the exposure at locality 56. Other specimens are from the Walnut, Goodland, Kiamichi, Duck Creek, Fort Worth, Denton, Weno, Paw Paw, Main Street, Grayson, Georgetown, Del Rio and Maness Formations. It also has been reported from the Glen Rose Formation of the Trinity Group in Texas.

Remarks. One of the most abundant species of Textulariopsis in the Gulf Coast mid Cretaceous, this species has a solid noncanaliculate wall as viewed in half-section in 
the SEM. It is agglutinated of calcareous particles and dissolves rapidly in $\mathrm{HCl}$.

\section{Textulariopsis texhomensis $\mathrm{sp}$. nov.}

(PI. 2, figs. 38, 39)

Derivation of name. With reference to the type locality of the species, from the excavation of the Denison Dam of the Red River which now forms Lake Texhoma at the boundary between Oklahoma and Texas.

Diagnosis. A species of Textulariopsis with an clongate, narrow, tapering test with chambers of early part little inflated and sutures flush with the surface, but chambers of later part inflated and sutures depressed.

Holotype. Specimen of Pl. 2, figs. 38, 39.

Material. Over 200 specimens.

Locality and horizon. Holotype from the Duck Creek Formation from a $1.6 \mathrm{~m}$ section of blue and yellow clays just beneath a heavy limestone bed, $2.5 \mathrm{~m}$ below top of excavation, and $17.6 \mathrm{~m}$ above the basal contact with the Kiamichi Formation at locality 104. Unfigured specimens are from the Duck Creek and Fort Worth Formations.

Description. Test free, elongate, narrow, biserial throughout or with a single adventitious chamber at the base appearing pseudotriserial, test increasing slowly in width with growth, rarely the test is twisted somewhat in the upper third, chambers with little or no inflation in early portion, with sutures flush with surface and directed very slightly downward toward the outer edge, later chambers inflated with sutures nearly horizontal and depressed; wall coarsely to finely agglutinated, of calcareous particles that dissolve in $\mathrm{HCl}$, wall solid; aperture a broad low arch at the base of the final chamber, occupying about half the width of the chamber face.

Dimensions. Holotype, length $0.86 \mathrm{~mm}$, width $0.28 \mathrm{~mm}$, thickness $0.24 \mathrm{~mm}$. Paratypes 0.22 to $1.03 \mathrm{~mm}$ long, 0.11 to $0.33 \mathrm{~mm}$ wide

Remarks. This species differs from Textularia inflata Gauger 1953 in tapering more rapidly, and in having a longer and thicker test. It differs from Textularia topagorukensis Tappan 1957 in being twice as large, and in its more inflated and more rounded cross-section. The wall is seen to be solid and noncanaliculate when half sectioned specimens are viewed in the SEM.

\section{Textulariopsis washitensis (Carsey, 1926)}

(Pl. 2, figs. 32-37)

1926 Textularia washitensis Carsey:34, pl. 7, fig. 6 .

Material. Several thousand specimens.

Locality and horizon. Figured hypotype (figs. 32, 33) from the Del Rio Formation, in a $1.6 \mathrm{~m}$ section of clay, beginning $3.3 \mathrm{~m}$ above the base of the exposure at locality 90. Figured hypotype (figs. 34, 35) from the Maness
Formation from mid portion of core at 3635-3665 feet, Shell S.T. Stephens No. 1. Figured hypotypes (figs. 36, 37) from the Grayson Formation in a $75 \mathrm{~cm}$ section beginning $4.5 \mathrm{~m}$ above base of exposure at locality 1 . Other specimens are from the Fort Worth, Denton, Weno, Paw Paw, Main Street, Grayson, Georgetown, Del Rio and Maness Formations.

Remarks. This large species is common in the upper part of the Washita Group. The wall is agglutinated of calcareous particles and dissolves in $\mathrm{HCl}$. Half sectioned specimens viewed under the SEM are seen to have a solid noncanaliculate wall as in other Textulariopsis. Occasional specimens have a tiny adventitious chamber at one side of the proloculus, giving the superficial appearance of a single triserial whorl, or even a pseudocoil. From the opposite side the true biserial nature is apparent.

\section{ACKNOWLEDGMENTS}

Subsurface material of the Maness Formation was originally sent to us for study by F.E. Lozo, and material from the Atlantic Blake Escarpment was obtained from Lamont-Doherty Geological Observatory.

This research was supported by Grant No. DEB8008085 from the Systematic Biology Program of the National Science Foundation. 


\section{REFERENCES}

Antonova, Z.A., Shmygina, T.A., Gnedina, A.G., \& Kalugina, O.M. 1964. Foraminifery Neokoma i Apta mezhdurech'ya Pshekha-Ubin (Severo-Zapadnyy Kavkaz) [Foraminifera of the Neocomian and Aptian between the Pshekha and Ubin Rivers (Northwest Caucasus)]. Trudy vses. neft. nauchno-issled. Inst., Krasnodarskiy Filial, 12, 3-72, pls. 1-14.

Banner, F.T. \& Pereira, P.G. 1981. Some biserial and triserial agglutinated smaller foraminifera: their wall structure and its significance. J. Foramin. Res., 11, 85-117, pls. 1-10.

Bartenstein, H., Bettenstaedt, F. \& Bolli, H.M. 1966. Die Foraminiferen der Unterkreide von Trinidad, W.I. Zweiter Teil: Maridale-Formation (Typlokalität). Eclog. geol. Helv., Lausanne, 59, 129-177, pls. 1-4.

Bartenstein, H. \& Bolli, H.M. 1973. Die Foraminiferen der Unterkreide von Trinidad, W.I. Dritter Teil: Maridaleformation (Co-Typlokalität). Eclog. geol. Helv., Lausanne, 66, 389-418, pls. 1-6.

Bartenstein, H. \& Brand, E. 1951. Mikropaläontologische Untersuchungen zur Stratigraphie des nordwestdeutschen Valendis. Abh. senckenb. naturforsch. Ges., Frankfurt, 485, 239-336, pls. 1-25.

Carsey, D.O. 1926. Foraminifera of the Cretaceous of central Texas. Bull. Univ. Tex. Bur. econ. Geol. Technol., 2612, 1-56, pls. 1-8.

Coleman, A.R. 1979. Sectioning microfossils-an old method revisited. J. Paleont., Chicago, 53, 508.

Coleman, A.R. 1980. Test structure and function of the agglutinated foraminifera Clavulina. J. Foramin. Res., 10, 142-152, pl. 1.

Cushman, J.A. 1927. An outline of a re-classification of the foraminifera. Contr. Cushman Lab. foramin. Res., 3, 1-105, pls. 1-21.

Cushman, J.A. \& Alexander, C.I. 1930. Some vaginulinas and other foraminifera from the Lower Cretaceous of Texas. Contr. Cushman Lab. foramin. Res., 6, 1-10, pls. 1-3.

Eicher, D.L. 1960. Stratigraphy and micropaleontology of the Thermopolis Shale. Bull. Peabody Mus. nat. Hist., New Haven, 15, 1-126, pls. 1-6.

Ericson, D.B., Ewing, M., Wollin, G. \& Heezen, B.C. 1961. Atlantic deep-sea sediment cores. Bull. geol. Soc. Am., New York, 72, 193-286.

Haig, D.W. 1980. Early Cretaceous textulariine foraminiferids from Queensland. Palaeontographica, Cassel, Abt. A, 170, 87-138, pls. 1-11.
Hofker, J. 1933. Papers from Dr. Th. Mortensen's Pacific Expedition 1914-16. LXII. Foraminifera of the Malay Archipelago. Vidensk. Meddr. dansk. naturh. Foren., 93, 71-167, pls. 2-6.

Hofker, J. 1951. The foraminifera of the Siboga Expedition. Siboga Exped., 3, 1-513.

Hofker, J. 1976. Further studies on Caribbean foraminifera. Uitg. natuurw. Stud-Kring Suriname, 49, $1-256$

Lalicker, C.G. 1935. New Cretaceous Textulariidae. Contr. Cushman Lab. foramin. Res., 11, 1-13, pls. $1,2$.

Loeblich, A.R. Jr. \& Tappan, H. 1946. New Washita foraminifera. J. Paleont., Chicago, 20, 238-258, pls. 35-37.

Lozo, F.E. 1951. Stratigraphic notes on the Maness (Comanche Cretaccous) Shale. Fondren. Sci. Ser., 4, 65-92, pls. 1, 2.

Maric, P. 1956. Sur quelques foraminifères nouveaux du Crétacé supérieur belge. Annls Soc. géol. Belg., 80, B235-B257, pls. 1-3.

Mikhalevich, V.I. 1975. Novyy rod i vid foraminifer (Foraminifera, Textulariidae) u Zapadnogo Poberezh 'ya Afriki [A new genus and species of foraminifer (Foraminifera, Textulariidae) from the western coast of Africa]. Vest. Zool. Kiev. (1), 86-87.

Moore, R.C. 1964 (Ed.). Treatise on Invertebrate Paleontology, Pt. C, Protista, 2 (1), xxxi + 510a pp., 399 figs. Univ. Kansas Press.

Parker, W.K. \& Jones, T.R. 1865. On some foraminifera from the North Atlantic and Arctic Oceans, including Davis Straits and Baffin's Bay. Phil. Trans. R. Soc., London, 155, 325-411, pls. 12-19.

Said, R. \& Barakat, M.G. 1958. Jurassic microfossils from Gebel Maghara, Sinai, Egypt. Micropaleontology, New York, 4 231-272, pls. 1-6.

Saidova, Kh. M. 1981. O sovremennom sostoyanii sistemy nadvidovykh taksonov kaynozoyskikh bentosnykh foraminifer. [On the present state of the system of supraspecific taxonomy of Cenzoic benthonic foraminifera]. 73 pp., Akad. Nauk SSSR, Inst. Okeanol. P.P. Shirshova. Moscow.

Tappan, H. 1940. Foraminifera from the Grayson Formation of northern Texas. J. Paleont., Chicago, 14, 93-126, pls. 14-19.

Tappan, H. 1943. Foraminifera from the Duck Creek Formation of Oklahoma and Texas. J. Paleont., Chicago, 17, 476-517, pls. 77-83. 